\title{
MARKETING RESEARCH OF TABLE EGGS MARKET
}

\author{
Ruslan Buriak', Maryna Rudenko², Ihor Chornodid ${ }^{3}$
}

\begin{abstract}
The object of research is the market for Ukrainian table eggs. Having analysed the domestic market for table eggs, the main trends are found there. The dynamics of the consumption of table eggs in our country over the last few years and the factors that have the greatest impact are studied. The aim of the article. The research is to analyse and assess the condition of the table eggs market. Methodology. The study was conducted using a systematic approach, using methods of economic-statistical, logical, and functional analysis. The factors that influence the level of competition of domestic enterprises in the market for eating eggs are determined. Established market concentration indicators and calculated the concentration coefficients and the Herfindahl-Hirschman index, which indicate a significant degree of concentration in the market of the four largest egg production companies and the tendency to reduce the share of giant companies in this market. Value/originality. It is established that the domestic market for table eggs is oligopoly with undeveloped competition, which negatively affects its development, updating of assortment and consumer prices. One of the leaders in the market of food eggs is AVANGARDCO IPL, which offers the market its rather diverse branded products. The peculiarities of the activity of the agroindustrial company "AVANGARDCO IPL" as the leading producer of eating eggs in the market for poultry products with a high technological level, quality of products, and supply stability are investigated. In the future, such enterprises will gradually eliminate products produced at enterprises with less technological production, and therefore, more expensive and less qualitative. The features that are inherent in organic products and have their specifics in the context of the poultry product subcomplex are determined. On the basis of the conducted researches, the peculiarities of the demand for organic eggs produced by AVANGARDCO IPL were determined, which allowed substantiating the priority of the development of organic production for this enterprise in the market of our state and the EU countries.
\end{abstract}

Key words: poultry products, table eggs, consumer market, eggs market, market concentration.

JEL Classification: Q13, Q11

\section{Introduction}

One of the main tasks of the agro-industrial complex of the country is providing food products to the population. A high-tech production, targeted at mass production of high-quality food products is crucial for modern agricultural economics. One of these high-tech industries is poultry keeping, organized on an industrial base. The demand for egg products is conditioned by physiological needs. To some extent, the demand depends on socio-economic factors and eating habits of the population. Chicken eggs are widely used in our country; they are eaten, used as ingredients in various dishes, and found their use in the food industry. Thus, formation and development of the egg market are crucial for the economy being one of the sources of food security (Dychakovska, 2014).

\section{Analysis of the latest researches and publications}

The works of well-known scholars, such as O. Berezin (2008) researched the peculiarities of agricultural production, their influence on the formation of flows of food resources, the conditions and factors of the formation of the national food market, the socioeconomic efficiency of its functioning, P. Sabluk (2008) studied perspectives of the development of the agro-industrial complex of Ukraine, L. Stranchynska (2008) proposed strategic directions of perspective development of national markets, and others are devoted to the peculiarities of the functioning of the food market in Ukraine. Scientific works of the well-known domestic economists-agrarians, such as R. Buriak (2011) studied to identify the factors influencing the formation of

\footnotetext{
Corresponding author:

${ }^{1}$ National University of Life and Environmental Sciences of Ukraine, Ukraine.

E-mail: ruslan1212@ukr.net

${ }^{2}$ National University of Life and Environmental Sciences of Ukraine, Ukraine.

E-mail: meri2006@ukr.net

${ }^{3}$ Academy of Labour, Social Relations and Tourism, Ukraine.

E-mail: chornodid@ukr.net
} 
market conditions, market research and development of medium-term forecast of the Ukrainian market of poultry products, D. Kiriliuk (2014) conducted research on the poultry market, I. Kishchak(2010) researched the state of the market for poultry and eggs in Ukraine is examined, factors influencing the increase in exports of poultry products, R. Myniv (2012) analysed the current trends of export-import of poultry eggs in Ukraine, S. Pashko (2015) investigated the economic mechanism of egg market functioning in Ukraine and in the countries of the world, Ya. Yanyshyna (2013) researched the different approaches to understanding the category of "efficiency"; on the basis of it, the definitions of economic efficiency in poultry are analysed, I. Yatsiv (2014) researched coefficients of export ponderability of poultry meat and eggs are calculated, and others show scientific research results devoted to the issues of development of poultry keeping.

The aim of the article is to analyse and assess the condition of the table eggs market.

Egg protein is considered a standard of protein for its qualitative composition; it is crucial for the human diet and is one of the most reasonable and common food products. Since some livestock products are not always reasonable for the low-income bracket, chicken eggs make a large part of the consumer demand for animal protein food products in Ukraine. The energy value of 100 grams of egg mass makes approximately $157 \mathrm{kcal}$ and its consumer price is approximately 3 to $4 \mathrm{UAH}$ based on the price of 18 UAH for ten eggs (prices of AVANGARDCO IPL dated September 29, 2017). 72 grams of boneless beef or 44 grams of pork makes the same energy value but the cost of these products is 2 to 2.5 times higher. Even the same energy value of milk ( 350 grams) will be more expensive for a consumer, not to speak of cheese.

Eggs are important for the human diet, providing the body with a well-digested and complete protein, vitamins, amino acids, and other substances the human body needs. In Ukraine, the average consumption of eggs per person in 2016, according to the State Statistics Service, was 267 pieces, which is $7.9 \%$ lower than the norm established by the Ministry of Healthcare of Ukraine (290 pieces). It is significantly reduced compared to the indicators of developed economy countries, where the average consumption of eggs reaches 300-350 pieces per person or more (State Statistics Service of Ukraine).

For the period from 2010 to 2016, the average consumption of eggs in Ukraine varied notably (Figure 1).

The maximum consumption of eggs for the period specified was observed in 2014 (310 pieces per person), minimal consumption was observed in 2016 (267 pieces per person). If for the period from 2012 to 2014 egg consumption has grown steadily, starting from 2014 there is a gradual decrease in the eggs consumption, and as of 2016 in Ukraine, only 267 eggs were consumed, or $86.13 \%$ ofindicator for 2014 . This reduction is caused both by a rise in the prices of eggs and reduction of income of the population (State Statistics Service of Ukraine).

\section{Theoretical substantiation of models of forecasting of marketing market for table eggs}

Eggs production is one of the most technological processes in livestock farming. It is marked with deterministic results of production and production process parameters optimized to achieve them to the greatest possible extent, thus reducing the products cost, increasing profitability and amount of profit, as well as accelerating the return on investments.

Effective eggs and egg products marketing is one of the main means of competitive struggle. Consumer

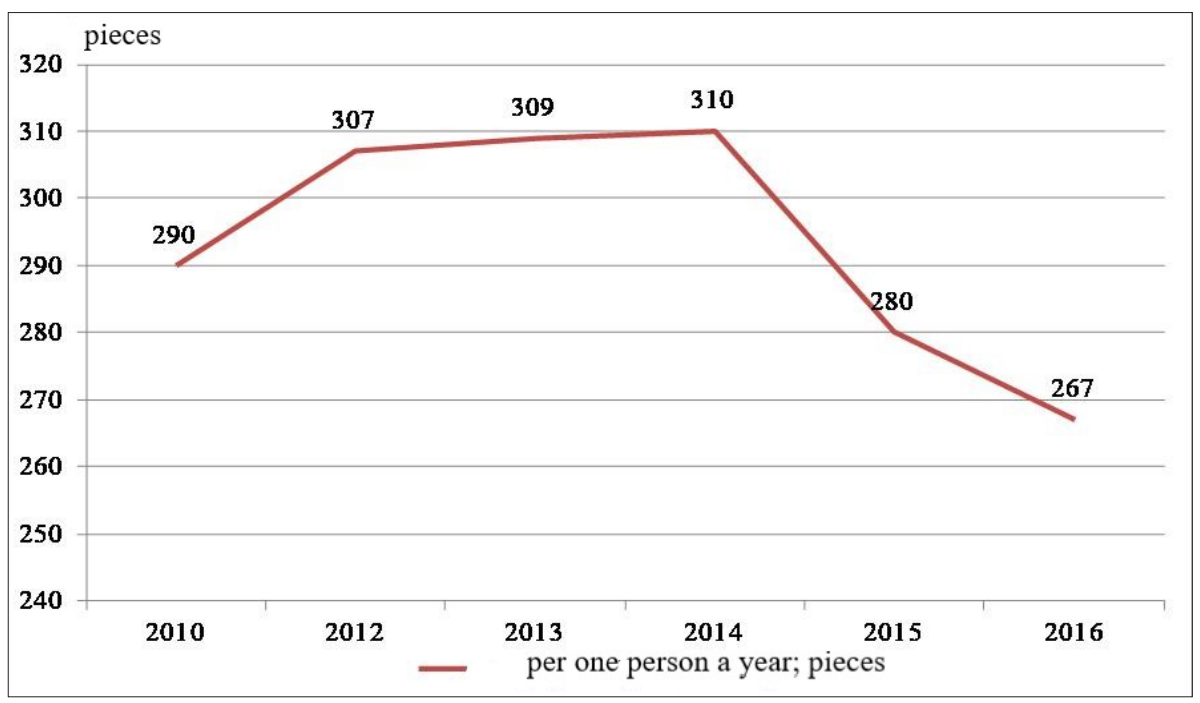

Figure 1. Dynamics of egg consumption in Ukraine for 2010-2016 
demands' understanding is a key to success in today's economy. Today, the consumers are becoming more aware of the eggs properties and quality than they were not so long ago. Experts in the eggs market should continuously monitor changes in consumers' tastes.

Limited shelf life and limited terms for sale of table eggs require special storage facilities and substantially influences the formation of the appropriate infrastructure making it possible to deliver products to the consumer within the shortest possible period of time. The role of the state in the formation and development of the market for these products is also important. The main tasks of state regulation in this sector are as follows: market prices control, agricultural producers and rural people profits support, rural people support, production incentive, processing, and consumption of eggs, as well as products export (Buriak, 2017).

Based on the researches, there have been summarized the external factors and the nature of their influence on the severity of competition on the table eggs market (Table 1).

Having analysed the data obtained, it is possible to determine the potential capacity of the table eggs market in Ukraine. To determine the consumer potential, the following formula was offered:

$$
P=C \cdot N \text {, }
$$

where $\mathrm{P}$ is the potential capacity of the consumer market, pieces of table eggs per year;

$\mathrm{C}$ is the average index of consumption of table eggs per year, pieces per person;

$\mathrm{N}$ is the country population.

The Ukrainian eggs market has a striking potential for development since the per caput eggs consumption in our country is much lower if compared to the average performance in Europe (over 350 pieces per person per year in the UK, Italy, France, and the Netherlands) (Pashko, 2015).

In 2016, the table eggs consumption was 267 pieces per person. Then the potential capacity of the domestic table eggs market, considering the statistically determined population in 2016 (42.7605 million people), will be:

$\mathrm{P}_{2016}=267 \cdot 42,7605=11,417$ billion pieces of table eggs per year.

It is important to note that the consumer potential of the domestic table eggs market will only grow in a few years thanks to the improvement of consumer culture and human wellbeing.

The demand for eggs is elastic. This is evident from the fact that a fair number of consumers are seeking cheaper products and reduces the consumption of eggs due to a price boom. Let us study the main producers of table eggs in the Ukrainian market (Table 2).

In 2016, the table eggs production output in Ukraine made 8.45 billion pieces, compared to 2015 with 8.06 billion pieces, showing that in 2016 the table eggs production has increased by 0,39 billion pieces or by 4.8\% compared to the same period in 2015 (Association of Poultry Breeders of Ukraine).

It should be noted that during the period being studied, as shown in Table 2, the main producers of table eggs in Ukraine are as follows: AVANGARDCO IPL, Group of Companies "Ovostar Union", and Inter-Zaporizhzhia; they are continuously reducing production outcomes. The dynamics of the share of the large companies market during this period resulted in the growth of the share of AVANGARDCO IPL

Table 1

Factors influencing the level of competition on the table eggs market

\begin{tabular}{|l|l|l|}
\hline \multicolumn{1}{|c|}{ Groups of factors } & \multicolumn{1}{|c|}{ The strongest factors } & \multicolumn{1}{|c|}{$\begin{array}{c}\text { Positive factors or factors having } \\
\text { no influence }\end{array}$} \\
\hline Consumers & $\begin{array}{l}\text { - slow growth of incomes of the population as the main consumer; } \\
\text { - high elasticity of demand for food products in terms of income and price; } \\
\text { - the possibility of changing the producer without additional expenses; } \\
\text { - a high level of awareness of the product and its price. }\end{array}$ & $\begin{array}{l}\text { - both intermediate consumers and } \\
\text { final consumers do not thread reverse } \\
\text { integration; } \\
\text { - consumers are numerous, different, } \\
\text { and non-concentrated. }\end{array}$ \\
\hline Suppliers & $\begin{array}{l}\text { - no alternative raw materials; } \\
\text { - the quality of raw materials determines the quality of the finished } \\
\text { product and the efficiency of production; } \\
\text { - there is a compelling need for obtaining new technologies for the } \\
\text { production of eggs packaging. }\end{array}$ & $\begin{array}{l}\text { - suppliers are more diverse and non- } \\
\text { concentrated; } \\
\text { - suppliers do not thread direct } \\
\text { integration for large eggs producers. }\end{array}$ \\
\hline Substitute products & $\begin{array}{l}\text { - the presence of “transition expenses" from the consumption of table } \\
\text { eggs to the consumption of other protein products; } \\
\text { - significant rates of production and reasonable price for the consumer; } \\
\text { - large producers offer lover prices with a wide range and high-quality } \\
\text { products. }\end{array}$ & $\begin{array}{l}\text { - no real threat of the occurrence of new } \\
\text { substitute products since today eggs are } \\
\text { the cheapest protein product }\end{array}$ \\
\hline $\begin{array}{l}\text { Existing and potential } \\
\text { competitors }\end{array}$ & $\begin{array}{l}\text { - there is a real threat of the occurrence of new competitors, due to large } \\
\text { foreign agricultural producers. }\end{array}$ & $\begin{array}{l}\text { - the existence of the enterprises that will } \\
\text { have a synergistic effect once entered } \\
\text { the market. }\end{array}$ \\
\hline
\end{tabular}

Source: summarized by the authors on the material 
Table 2

The main producers of table eggs in Ukraine in 2015-2016

\begin{tabular}{|c|c|c|c|c|c|c|}
\hline \multirow{2}{*}{ Producer } & \multicolumn{2}{|c|}{ Production output, billion pieces } & \multicolumn{3}{c|}{ Market share, $\%$} \\
\cline { 2 - 7 } & 2015 & 2016 & deviation, $\%$ & 2015 & 2016 & deviation, $\%$ \\
\hline AVANGARDCO IPL & 2,61 & 2,50 & $-4,2$ & 30,9 & 31 & 0,1 \\
\hline Group of Companies “Ovostar Union” & 1,57 & 1,51 & $-4,0$ & 18,6 & 18,7 & 0,1 \\
\hline Inter-Zaporizhzhia & 0,95 & 0,79 & $-16,5$ & 11,2 & 9,8 & $-1,4$ \\
\hline Avias 2000 TOV & 0,64 & 0,44 & $-32,2$ & 7,6 & 5,4 & $-2,2$ \\
\hline Krupets Agri Corporation & 0,20 & 0,17 & $-16,5$ & 2,4 & 2,1 & $-0,3$ \\
\hline Poultry Factory Podillya & 0,11 & 0,08 & $-26,6$ & 1,3 & 1 & $-0,3$ \\
\hline Ternopilska Poultry Farm PJSC & 0,10 & 0,08 & $-20,4$ & 1,2 & 1 & $-0,2$ \\
\hline Other poultry farms & 2,26 & 2,50 & 10,4 & 26,8 & 31 & 4,2 \\
\hline Totally eggs produced & 8,45 & 8,06 & $-4,5$ & 100 & 100 & $\mathrm{X}$ \\
\hline
\end{tabular}

Source: developed by the authors

(31\% of the market in 2016); stabilization after the recession in Group of Companies "Ovostar Union" (18.7\% of the market share in 2016) and reduction of market positions of Inter-Zaporizhzhia by 1.4\% (9.8\% of the market in 2016). Other companies showed a reduction in both sales and market share.

To make the quantitative assessment of the concentration level, it is offered to use the concentration coefficient and the Herfindahl-Hirschman indexes. The first indicator (IK concentration coefficient) characterizes the share of the aggregate sale of products in the market, which falls on 4 leading enterprises:

$$
I K=\sum_{i=1}^{4} P_{i}
$$

where $I K$ is the concentration coefficients; $P_{i}$ is the share of the leading enterprise of the industry, $\%$.

The Herfindahl-Hirschman indexes (IXX) define an index of market concentration as the sum of the squares of market shares, expressed as a percentage of all companies selling products in this market:

$$
\text { IXX }=\sum_{i=1}^{n} \boldsymbol{P}_{i}^{2}
$$

where IXX is the Herfindahl-Hirschman indexes; $n$ is the number of companies in the market;

$P_{i}$ is the share of the leading enterprise of the industry, $\%$.

To reflect the typology of the table eggs market, we will calculate the above-mentioned coefficients. Estimated data and outcomes are shown in Table 3.
According to the concentration coefficient, calculated based on the share of the four largest enterprises, there is a high level of concentration on the market being studied (68.3\% and $64.9 \%>60 \%)$. However, the dynamics show the decrease in the share of large enterprises. If in 2015 the share of other egg producers made $29.8 \%$, in 2016 it was $31 \%$, the same showed the market leader, AVANGARDCO IPL.

The Herfindahl-Hirschman indexes show the market share of all market participants. For the sake of convenience, other producers were classified as 'other producers'. The Herfindahl-Hirschman indexes studied in the dynamics for the 'other producers' category are less than 1800 (since four largest enterprises amount to 1483.97 in 2015 and to 1435.89 in 2016). However, we can tell that the table eggs market in Ukraine has not yet been monopolized, although having a high level of concentration. This is evident from the fact that the market considered safe for the positive competition if the share of one company does not exceed $31 \%$. Thus, following the results of 2016, the largest producer AVANGARDCO IPL holds the share of exactly $31 \%$ being a critical value whose increase will destroy the condition of positive competition (Group of Companies 'Avangard').

The quality of products and the stable supply is all eggs production sector needs to succeed on the domestic market. Consequently, the products with the higher

Table 3

Monopolization dynamics of the table eggs market in Ukraine

\begin{tabular}{|c|c|c|c|c|}
\hline \multirow{2}{*}{ Companies } & \multicolumn{2}{|c|}{2015} & \multicolumn{2}{c|}{2016} \\
\cline { 2 - 5 } & market share, \% & squared share & market share, \% & squared share \\
\hline AVANGARDCO IPL & 30,9 & 954,81 & 31,0 & 961 \\
\hline Group of Companies “Ovostar Union” & 18,6 & 345,96 & 18,7 & 349,69 \\
\hline Inter-Zaporizhzhia & 11,2 & 125,44 & 9,8 & 96,04 \\
\hline Avias 2000 TOV & 7,6 & 57,76 & 5,4 & 29,16 \\
\hline Others & 2,4 & 5,76 & 2,1 & 4,41 \\
\hline IK & 68,3 & - & 64,9 & 479,3 \\
\hline IXX4 & & 534,92 & & 483,71 \\
\hline IXX
\end{tabular}

Source: developed by the authors 
prices and lower quality will be gradually driven from the market by the products produced at enterprises with a higher technical level.

Today there is a group of egg processing companies in Ukraine whose technical equipment correspond to the highest world level. One of them is AVANGARDCO IPL. It is one of the largest agro-industrial companies in Ukraine producing chicken eggs and dry egg powder. As of year-end 2016, the company holds $31 \%$ of the industrial eggs market and $87 \%$ of the egg powder market in Ukraine. The stock of laying chickens of AVANGARDCO IPL is one of the largest in the world. The company introduces new and upgraded technologies in its work: egg products fermentation, deep egg components separation; new eggs pasteurization and sterilization technologies, etc. - and provision of leading world companies with hardware. The products of AVANGARDCO IPL are demanded both in Ukraine and abroad.

\section{Justification of marketing strategies for eco-products of poultry farms}

The most popular brands of table eggs produced by AVANGARDCO IPL are packaged eggs 'Kvochka' (76\% of sales of leased table eggs), 'Domashni' (19\%), and 'Organic Eggs' (5\%) being certified organic table eggs. Trademark 'Organic Eggs' is a special product for AVANGARDCO IPL. The company moves with the times and offers Ukrainian consumers a modern organic product especially for those wishing to consume organic food. Today, Ukraine is at the initial stage of formation of the national market for organic products and this market room is still open. 'Organic Eggs' brand occupies the leading position in the portfolio of the trademark 'Kvochka' and represents the main values of AVANGARDCO IPL, in particular, fresh and natural products. The motto: 'Organic Eggs' is the maximum natural benefit (Group of Companies 'Avangard').

We have studied the consumption of organic eggs and created a consumption-prices level dependence model. The hypothesis of the study is the low degree of dependence of the level of consumption of organic eggs on the level of consumer prices since this product is classified as unique in terms of energy and nutritional qualities. To support the low degree of dependence of the level of consumption of 'Organic Eggs' organic eggs on the level of consumer prices, we will use the correlation-regression analysis method. The level of average consumer prices and retail sales volumes of 'Organic Eggs' eggs per month for 2015-2016 will be the initial data. As a result, we obtain a correlation field characterizing the dependence of the egg consumption level on the retail price for ten eggs (Figure 2).

The lack of a correlation between the indicators being studied is demonstrated by a quite chaotic arrangement of points in the graph. To receive a mathematical support of this conclusion, let us show several pair regression equations characterizing the dependence of the level of consumption of 'Organic Eggs' eggs $(\mathrm{Y})$ on the average retail price for ten eggs $(\mathrm{X})$ (Table 4$)$.

In the pair regression equations presented, the determination coefficient varies within the range of 0.1932-0.2 proving the lack of significant connection between the phenomena being studied.

The results of correlation-regression analysis confirm the low degree of dependence of the level of consumption of 'Organic Eggs' eggs on their average consumer price. This supports the strategic prospect of further development of this trademark for AVANGARDCO IPL.

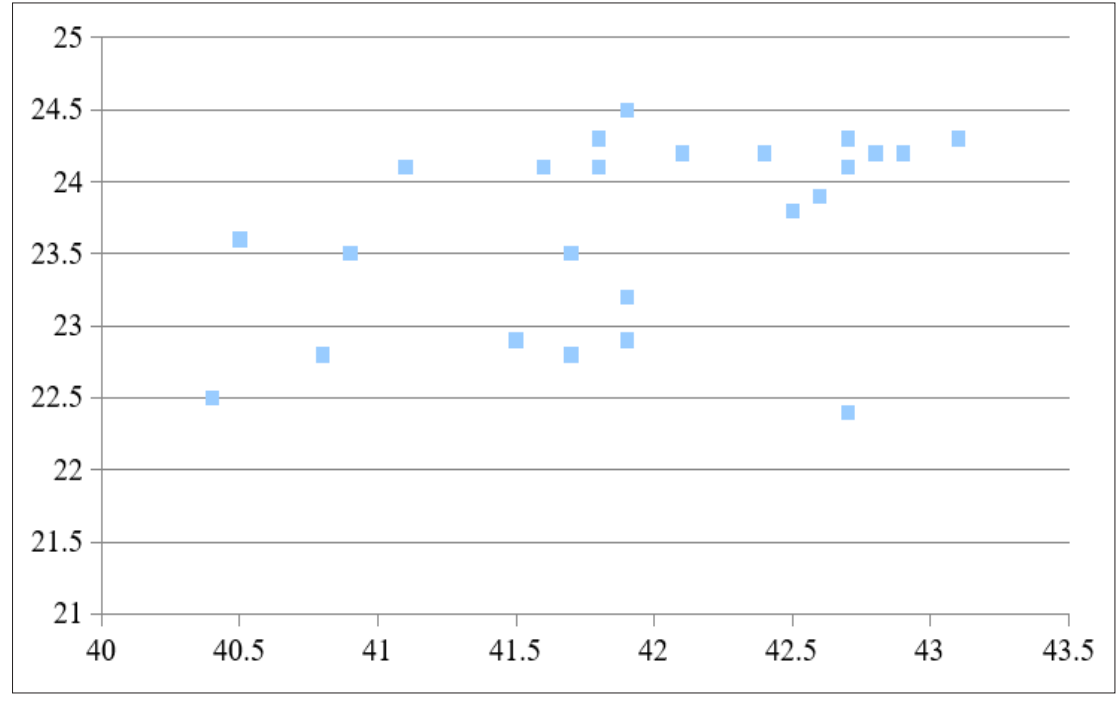

*axis OX - price of UAN/ten pcs., axis OY - sales volume, million, pcs.

Figure 2. The level of eggs 'Organic Eggs' consumption per quarter depending on their retail price in the period from 2015 to 2016 
Table 4

Comparative estimation of the accuracy of the pair regression models

\begin{tabular}{|c|c|c|}
\hline Function type & Equation & Determination index $\left(\mathrm{R}^{2}\right)$ \\
\hline Linear & $\mathrm{Y}=0,3731 \mathrm{X}+8,0435$ & $\mathrm{R}^{2}=0,1953$ \\
\hline Square & $\mathrm{Y}=-0,0739 \mathrm{X}^{2}+6,547 \mathrm{X}-120,85$ & $\mathrm{R}^{2}=0,2$ \\
\hline Degree & $\mathrm{Y}=2,0011 \mathrm{X}^{0,6614}$ & $\mathrm{R}^{2}=0,1938$ \\
\hline Exponential & $\mathrm{Y}=12,2 \mathrm{e}^{0,0158 \mathrm{X}}$ & $\mathrm{R}^{2}=0,1932$ \\
\hline Logarithmic & $\mathrm{Y}=15,603 \ln (\mathrm{X})-34,6$ & $\mathrm{R}^{2}=0,1959$ \\
\hline
\end{tabular}

Source: developed by the authors

\section{Conclusions}

Having analysed the domestic egg products market, we can say that the market is oligopolistic with weak competition affecting its development, assortment updating, and consumer prices. One of the leaders on the eggs market is AVANGARDCO IPL, offering the market the branded products of the trademark 'Kvochka', among which 'Organic Eggs' organic eggs brand occupies the top position in the portfolio and is one of the most advanced for AVANGARDCO IPL.

Organic products are more expensive and organic poultry products, especially egg products have the highest prices among others. This is due to the fact that the production of eggs has the shortest production cycle among livestock industries and poultry farms, by optimizing rations, managed to achieve the maximum reduction in the production cost for the products received. Thus, the price for eggs in eco-shops exceeds the price in trading networks by a mean of 2-2.4 times. The abovementioned facts show that today the consumer segment of ecological products consists of the middle-class consumers whose family budget is not significantly affected by the high price of quality products (Generowicz, Kowalski, Banach, 2012).

However, it should be noted that the market for egg food in Ukraine is not yet monopolized, although it has a significant level of concentration. This is also evidenced by the fact that the market for maintaining "healthy" competition is considered safe if one firm holds no more than $31 \%$ on it.
Organic products are higher in price and the greatest excess of prices for environmental products is observed in poultry products, including egg products. This can be explained by the fact that the production of eggs has the shortest production cycle in livestock industries, and poultry farms by optimizing rations have been able to achieve the maximum reduction in the cost price of the products received. Thus, the price of eggs in eco-shops exceeds their cost in trading networks by an average of 2-2.4 times. The above facts indicate that at present, the consumer segment of ecological products is people with a higher than average wealth, for whom the high cost of quality products does not fundamentally affect the family budget.

In conclusion, it should be noted that one of the advantages of the organic products market is the increasing demand for organic products in Ukraine. This is shown by the increasing sales volumes of 'Organic Eggs' organic eggs brand produced by AVANGARDCO IPL, as well as the low sensitivity of sales of table eggs of this brand to the price change. However, low level of incomes of the population puts back the organic products market development.

Today, AVANGARDCO IPL with its product 'Organic Eggs' strives to enter foreign markets and export high value-added products. Once Ukraine signed the EU Association Agreement, the domestic market for organic products received all the chances to become an exporter of organic products to developed countries.

\section{References:}

Berezin, O. V. (2008). Food market of Ukraine: theoretical and methodological principles of formation and development. Kiev: Center for Educational Literature. (in Ukrainian)

Buriak, R. I. (2011). Management of quality of poultry products. Kiev: Agrar Media Group LLC. (in Ukrainian)

Buriak, R. I. (2017). Research and forecasting of the state of poultry market in Ukraine. Retrieved from: http://journals.nubip.edu.ua/ (in Ukrainian)

Dychakovska, V. (2014). Market of poultry and eggs: stable development. Retrieved from: http://www.agrotimes.net Generowicz, A., Kowalski, Z., Banach, M. \& et al. (2012). A Glance at the World. Waste Management, 32(2), 349-350.

Kishchak, I. T. (2010). Analysis of the market of poultry and eggs in Ukraine. Collection of scientific works of the ChDTU, 25, 71-73. (in Ukrainian)

Kvasha, S. M., Vlasov, V. I. \& Kryvenko, N. V. (2013). Export and import of agricultural products in Ukraine: state and trends. Kiev: Universitetska kniha. (in Ukrainian)

Kyryliuk, D. O. (2014). Analysis of the current state of poultry market in Ukraine. Economy of the agro-industrial complex, 2, 116-119. (in Ukrainian) 
Myniv, R. M. (2012). The effectiveness of egg and poultry farming in Ukraine. Scientific bulletin of Lviv National University of Veterinary Medicine and Biotechnology named after S. Z. Hzhytskyi, 3, 52-59. (in Ukrainian)

Myniv, R. M. (2013). The analysis of export and import of chicken eggs in Ukraine. Scientific bulletin of Lviv National University of Veterinary Medicine and Biotechnology named after S. Z. Hzhytskyi, 2, $227-232$. (in Ukrainian)

Official site of the Association of Poultry Breeders of Ukraine. Retrieved from: http://www.poultryukraine.com/ en/poultry/news/

Official website of a Group of Companies 'Avangard'. Retrieved from: http:/ / avangardco.ua

Official website of the Ministry of Agrarian Policy and Food of Ukraine. Retrieved from: http://minagro.gov.ua

Official website of the State Statistics Service of Ukraine. Retrieved from: http://www.ukrstat.gov.ua

Pashko, S. O. (2015). Ukrainian market of chicken eggs and its place in the world. Economy and Management of agro-industrial complex, 1, 44-48. (in Ukrainian)

Sabluk, P. (2008). The state and perspectives of the development of the agro-industrial complex of Ukraine. Economy of Ukraine, 12, 4-18. (in Ukrainian)

Strashynska, L. (2008). Ukrayini Strategy for the development of the food market in Ukraine. Kiev: Profi. (in Ukrainian)

Yanyshyn, Ya., Bulyk, O. \& Tymofiyv T. (2013). Theoretical basis of the poultry production effectiveness. Agrarian economy, 3-4, 74-80. (in Ukrainian)

Yatsiv, I. \& Zaviriukha A. (2014). Competitiveness of Ukrainian poultry production on the foreign markets, 3-4, 72-78. (in Ukrainian)

Zelisko, N., Krupa, V. (2013). Factors of formation of competitive advantages of agro-industrial complex in Ukraine while integrating into the global economy. Agrarian economy, 3-4, 49-54. (in Ukrainian) 